\title{
Desain Komunikasi Visual Sebagai Media Informasi Pada Kelurahan Kebon Besar Kota Tangerang
}

\author{
Wendy Andriyan ${ }^{1, *}$, Sindiawati ${ }^{1}$, Ghina Puspita Kurnia ${ }^{1}$ \\ 1 Teknik Informatika; Universitas Raharja; JL. Jendral Sudirman, No.40, Modern Cikokol, \\ Tangerang 15117; e-mail: wendy@raharia.info, sindiawati@raharja.info, \\ ghina.puspita@raharia.info \\ * Korespondensi: e-mail: wendy@raharja.info
}

Diterima: 22 April 2020; Review: 28 April 2020; Disetujui: 3 Mei 2020

Cara sitasi: Andriyan W, Sindiawati, Kurnia G P. 2020. Desain Komunikasi Visual Sebagai Media Informasi Pada Kelurahan Kebon Besar Kota Tangerang. Bina Insani ICT Journal. Vol.7(1) : 73-82.

\begin{abstract}
Abstrak: Perkembangan teknologi informasi yang semakin pesat dari dulu hingga sekarang menciptakan suatu kondisi dimana manusia ingin mendapatkan kebutuhan sumber informasi yang di inginkan secara mudah, cepat dan akurat. Salah satunya adalah Desain Komunikasi Visual yang memiliki peran sangat penting agar masyarakat dapat memahami dengan mudah isi dari informasi yang diterima. Berdasarkan penggunaannya, Desain Komunikasi Visual akan sangat efektif bagi Kelurahan Kebon Besar Kota Tangerang. Dikarenakan, dalam penyampaian informasi mengenai kegiatan program sosialisasi kepada masyarakat yang dilakukan oleh Kelurahan Kebon Besar Kota Tangerang masih belum tersalurkan dengan baik. Saat ini, penyampaian informasinya masih dari orang ke orang melalui komunikasi lisan yang dapat menyebabkan kesalahan penyampaian informasi. Maka dari itu, setiap kegiatan program sosialisasi yang dilakukan oleh Kelurahan Kebon Besar Kota Tangerang membutuhkan media informasi yang di buat dengan media cetak seperti spanduk, poster dan brosur agar informasinya mudah dipahami dan mencegah kesalahan penyampaian informasinya. Adapun metode yang digunakan pada penelitian ini yaitu observasi, wawancara dan studi pustaka. Penelitian ini menghasilkan sebuah desain kreatif sebagai media informasi pada Kelurahan Kebon Besar Kota Tangerang.
\end{abstract}

Kata kunci: desain, informasi, program sosialisasi

\begin{abstract}
The rapid development of information technology from the beginning until now creates a condition where humans want to get the needs of the desired source of information easily, quickly and accurately. One of them is Visual Communication Design which has a very important role so that people can easily understand the contents of the information received. Based on its use, Visual Communication Design will be very effective and efficient for the Kebon Besar Village, Tangerang City. Because, in the delivery of information about the program of socialization activities to the community carried out by the Kebon Besar Village, Tangerang City has not been distributed properly. At present, the delivery of information is still from person to person through verbal communication which can cause errors in delivering information. Therefore, every program of socialization activities carried out by Kebon Besar Village, Tangerang City requires information media made with printed media such as banners, posters and brochures so that the information is easily understood and prevents misinformation. The method used in this research is observation, interview and literature study. This research resulted in a creative design as information media in Kebon Besar Village, Tangerang City.
\end{abstract}

Keywords: design, information, socialization program 


\section{Pendahuluan}

Pada era revolusi 4.0 saat ini, penyampaian informasi telah berevolusi menjadi sesuatu yang lebih maju dan perlahan meninggalkan cara lama yang dapat mengakibatkan kesalahan penerimaan isi dari informasi. Sering kali informasi yang diterima menggunakan cara lama sulit dipahami karena penyampaiannya yang terkadang kurang jelas. Cara lama yang dimaksud adalah penyampaian informasi dengan cara komunikasi lisan, yaitu sebuah komunikasi dimana pesan atau pertukaran informasi dengan kata-kata yang diucapkan. Hal ini dapat dilakukan oleh kedua tatap muka dan juga melalui perangkat mekanis [1]. Dilihat dari cara penggunaannya, komunikasi lisan memiliki kekurangan, diantaranya memerlukan adaptasi atau penyesuaian kondisi dan situasi terlebih dahulu sebelum berkomunikasi, memerlukan suatu uraian dan penjelasan yang lebih detai, dan sulit untuk didokumentasikan tanpa bantuan alat recording [2]. $\mathrm{Hal}$ inilah yang membuat penyampaian informasi dengan cara lama tidaklah efektif, seperti seseorang yang diberikan kepercayaan untuk menyampaikan informasi kepada satu atau banyak orang akan tetapi informasi yang diterimanya kurang dimengerti atau kurang jelas. Sehingga memungkinkan informasi yang disampaikannya menjadi informasi yang keliru dan sulit dipahami.

Adapun faktor lainnya yaitu faktor ingatan, dimana setiap orang memiliki kemampuan mengingat yang berbeda-beda. Dalam hal ini, terjadinya kelupaan informasi bisa menjadi masalah yang serius dalam pelaksanaaan tujuan yang sudah direncanakan. Hal ini diperkuat karena adanya memori jangka pendek yang dimiliki oleh manusia. Ingatan jangka pendek adalah suatu proses penyimpanan memori sementara dimana informasi akan disimpan selama informasi itu dibutuhkan. Sistem ingatan jangka pendek menyimpan informasi atau stimuli selama sekitar 30 detik. Dari ingatan jangka pendek ini, sebagian informasi yang terpilih akan diteruskan ke dalam ingatan jangka panjang. Jika kita mengingat kembali tentang sebuah informasi, maka informasi yang tersimpan dalam ingatan jangka panjang akan dikembalikan ke ingatan jangka pendek untuk di recall [3]. Dalam pemerintahan, kesalahan informasi yang disampaikan dapat merusak kepercayaan publik seperti berkurangnya citra dan reputasi pemerintahan.

Sebagai lembaga pemerintahan yang memiliki hubungan dengan masyarakat, tentunya Kelurahan Kebon Besar Kota Tangerang memiliki peran yang sangat penting dalam menyebarluaskan informasi dan kebijakan pemerintah sesuai dengan institusi/lembaga masingmasing kepada publik, menampung dan mengolah aspirasi masyarakat, serta membangun kepercayaan publik guna menjaga citra dan reputasi pemerintah. Untuk itu diperlukan upayaupaya kreatif dan persuasif dalam pelaksanaan misi tersebut. Tidak hanya itu, sebagai salah satu lembaga pemerintahan, Kelurahan Kebon Besar Kota Tangerang harus bisa mengomunikasikan kebijakan, rencana kerja dan capaian kinerja kepada masyarakat luas, melalu media tradisional, media konvensional, dan media baru. Komunikasi yang menggunakan media baru atau teknologi internet dapat menjangkau langsung dan cepat kepada semua pihak [4].

Tetapi sayangnya, penyebaran informasi yang digunakan oleh Kelurahan Kebon Besar Kota Tangerang masih menggunakan komunikasi lisan yang kurang menggunakan bantuan teknologi dalam membuat media-media penyampaian informasi yang lebih efektif, seperti media Desain Komunikasi Visual yang merupakan seni dalam menyampaikan informasi atau pesan dengan menggunakan bahasa rupa/visual yang disampaikan melalui media yang berupa desain. Bertujuan untuk menginformasikan, mempengaruhi hingga merubah perilaku target (audience) sesuai dengan tujuan yang ingin diwujudkan [5]. Dengan penerapannya, kegiatan program sosialisasi yang ingin disampaikan kepada warga Kelurahan Kebon Besar Kota Tangerang dapat mencegah kesalahan penerimaan informasi yang terjadi akibat menggunakan komunikasi lisan. Pernyataan tersebut dapat diperkuat, dibandingkan dengan bahasa lisan dan tulisan, bahasa gambar lebih mudah dimengerti sehingga pesan yang disampaikan menjadi lebis jelas diterima [6]. Tidak hanya itu saja, penggunaan media Desain Komunikasi Visual dapat meningkatkan citra dan menjaga reputasi Kelurahan Kebon Besar Kota Tangerang, karena telah memberikan kesan baik dimata masyarakat dengan memperhatikan pengelolaan sumber media informasinya dalam mensosialisasikan setiap program kegiatan yang dilakukan. Menyikapi hal tersebut, peneliti berinisiatif untuk membantu mengembangkan sarana informasi melalui media cetak untuk memperlancar setiap kegiatan program sosialisasi yang dilakukan oleh Kelurahan Kebon Besar Kota Tangerang. 


\section{Metode Penelitian}

Pada gambar 1 merupakan metode penelitian yang dilakukan oleh penulis diantaranya ada metode analisa permasalahan, metode pengumpulan data yang di dalamnya ada, observasi, wawancara dan studi Pustaka, lalu dilanjutkan dengan metode analisa data dan metode desain. Agar dapat mengatasi berbagai masalah yang ada maka didalam penelitian ini penulis menerapkan empat metode, berikut adalah penjelasannya:

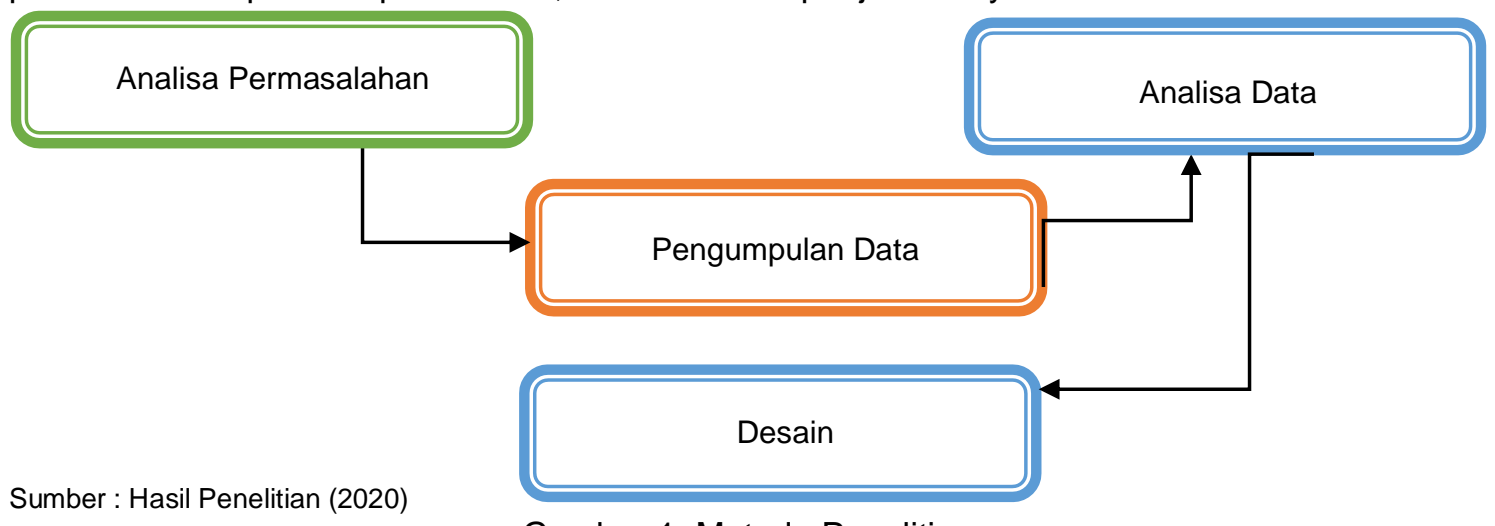

Gambar 1. Metode Penelitian

Metode yang pertama adalah analisa permasalahan, analisa adalah menyelidiki, menguraikan, menelaah suatu permasalahan untuk mengetahui pemahaman yang tepat [7]. Dalam hal ini penulis menganalisa permasalahan yang terjadi pada Kelurahan Kebon Besar Kota Tangerang yang berfokus pada penggunaan media penyampaian informasinya sebagai bentuk sosialisasi mengenai program sosialisasi yang akan dilakukan pada Kelurahan Kebon Besar Kota Tangerang.

Metode yang kedua adalah pengumpulan data yang di dalamnya ada observasi, yaitu metode pengumpulan data yang menggunakan pengamatan terhadap obyek penelitian. Observasi dapat dilaksanakan secara langsung maupun tidak langsung [8]. Dalam hal ini penulis melakukan pengambilan data melalui pengamatan dan pencatatan secara sistematik terhadap unsur-unsur yang telah diteliti untuk mencari permasalahan yang terjadi dalam penyampaian informasi kepada masyarakat mengenai kegiatan program sosialisasi yang dilakukan oleh Kelurahan Kebon Besar Kota Tangerang. Selanjutnya wawancara, yaitu proses memperoleh keterangan untuk tujuan penelitian dengan cara tanya jawab sambil bertatap muka antara si penanya atau pewawancara dengan si penjawab atau responden dengan menggunakan alat yang dinamakan interview guide (panduan wawancara) [9]. Dalam hal ini penulis melakukan wawancara secara tatap muka langsung dengan kader desa selaku orang yang diwawancarai untuk memperoleh gambaran yang lebih jelas mengenai proses penyampaian informasi mengenai kegiatan program sosialisasi yang sedang berjalan di Kelurahan Kebon Besar Kota Tangerang. Dilanjutkan dengan studi Pustaka, yaitu suatu metode pengumpulan data yang diambil dari perpustakaan atau instansi yang berupa karya ilmiah, jurnal, buku-buku serta dari internet yang berhubungan dengan penulisan ini. Tujuan dari studi pustaka ini adalah untuk mendalami dan memperoleh keterangan yang lengkap terhadap obyek yang diteliti [10].

Metode yang ketiga adalah analisa data menggunakan deskriptif kualitatif, Adapun metode deskriptif kualitatif ditujukan untuk mengumpulkan informasi secara aktual dan terperinci, mengidentifikasi masalah, membuat perbandingan atau evaluasi, dan menentukan apa yang dilakukan orang lain dalam menghadapi masalah yang sama dan belajar dari pengalaman mereka untuk menetapkan rencana dan keputusan di waktu mendatang [11]. Dalam hal ini penulis merangkum hal pokok, fokus pada hal-hal penting, mencari pola dan alurnya seperti apa. Hal ini berujuan untuk menyederhanakan data yang diperoleh selama pengumpulan data di tempat penelitian melalui proses observasi, wawancara dan studi pustaka.

Metode yang terakhir adalah desain explosing yaitu membuat desain yang baru dengan cara mencari inspirasi dengan berpikir secara kritis berdasarkan permasalahan yang ada mengenai penggunaan media informasi Kelurahan Kebon Besar Kota Tangerang. 


\section{Hasil dan Pembahasan Analisa Permasalahan}

Hasil dari analisa permasalahan yang dilakukan adalah kurang efektifnya penyampaian informasi yang dilakukan oleh Kelurahan Kebon Besar Kota Tangerang karena masih menggunakan komunikasi lisan, yaitu penyampaian informasi dari orang ke orang atau dari mulut ke mulut yang akan memakan waktu dan memungkinkannya terjadi kesalahan dalam penyampaian informasi maupun penerimaan informasi, sehingga apabila adanya penyampaian informasi yang kurang tepat akan membuat masyarakat bingung dan meragukan informasi yang diterima. Jika hal itu sampai terjadi maka kinerja Kelurahan Kebon Besar Kota Tangerang akan dipertanyakan mengenai pelayanannya terhadap masyarakat, khususnya pada programprogram sosialisasi untuk masyarakat.

\section{Pemecahan Masalah}

Berdasarkan analisa permasalahan yang telah diuraikan, terdapat pemecahan masalah yang dapat dilakukan, diantaranya adalah menambah media informasi baru sebagai sarana pendukung penyampaian informasi yang saat ini digunakan (komunikasi lisan) menjadi lebih efektif dan dapat meminimalisir kesalahan penyampaian informasi antara orang yang menyampaikan dan orang yang menerima informasi. Dalam hal ini, penambahan media informasi yang dimaksud adalah media desain seperti brosur, spanduk dan poster. Pada era teknologi dan digital saat ini, akan sangat disayangkan apabila teknologi tidak dimanfaatkan dengan baik dalam hal penyampaian informasi. Dengan sentuhan teknologi, akan sangat mudah membuat media-media pendukung informasi yang kreatif dan unik. Dalam melakukan penambahan media informasi ini juga, masyarakat akan menilai bahwa Kelurahan Kebon Besar Kota Tangerang benar-benar serius memperhatikan sumber daya informasi, sehingga hal itu dapat membangun citra dan reputasi Kelurahan Kebon Besar Kota Tangerang.

\section{Pengertian Media}

Media adalah suatu wadah yang digunakan untuk mengkomunikasikan sebuah pesan atau informasi kepada si penerima dengan melibatkan rangsangan indera penglihatan. Dalam hal ini, media yang dimaksud adalah media desain. Sebuah media yang akan digunakan untuk memvisualisasikan pesan atau informasi dalam suatu bentuk dengan perpaduan seperti gambar, teks dan warna yang dibuat dalam sebuah media. Salah satu media yang digunakan pada proses desain adalah media cetak, dimana untuk melakukan proses visualisasinya harus di cetak terlebih dahulu.

\section{Tujuan Media}

Adapun tujuan dibuatnya media Desain Komunikasi Visual ini adalah sebagai bentuk penambahan media informasi yang bertujuan untuk membantu kinerja Kelurahan Kebon Besar Kota Tangerang dalam menyampaikan informasi kegiatan program sosialisasi kepada masyarakat yang akan berlangsung sehingga maksud dan tujuan informasi yang ingin disampaikan dapat dipahami dengan mudah oleh si penerima informasi. Media yang digunakan sebagai media penunjang informasi mengenai program sosialisasi pada Kelurahan Kebon Besar Kota Tangerang adalah media poster luar ruangan yang dibuat untuk mengucapkan selamat hari sumpah pemuda ke-91 tahun yang ada dilingkungan Kelurahan Kebon Besar Kota Tangerang, media spanduk yang dibuat untuk mengucapkan selamat memperingati hari pahlawan kepada seluruh masyarakat dan keluarga Kelurahan Kebon Besar Kota Tangerang, media brosur yang dibuat untuk menginformasikan mengenai festival kampung pemuda, media poster yang dibuat untuk menginformasikan pentingnya imunisasi agar masyarakat bisa mencegah penyakit untuk buah hatinya, dan media brosur yang dibuat untuk menginformasikan mengenai pengambilan Program BPNT (Bantuan Pangan Non Tunai).

\section{Strategi Media}

Dalam menunjang nilai efektifitas sarana media yang dirancang, strategi media informasi adalah dengan menggunakan bentuk media poster, spanduk dan brosur, secara visual orientasi gambar-gambar tampilan dibuat semenarik mungkin dengan perpaduan gambar, warna dan teks yang nantinya tidak hanya informasi yang tersampaikan dengan efektif, melainkan dapat menargetkan rasa tertarik masyarakat mengenai informasi yang disampaikan dan program-program sosialisasi yang akan berlangsung. Hal tersebut secara visual untuk 
memenuhi 3 aspek sasaran yaitu: Geografi: Warga kelurahan Kebon Besar Kota Tangerang. Demografi: Jenis Kelamin: Pria \& Wanita, Kelas Ekonomi: Umum (mencakup seluruh kelas ekonomi), Sasaran: Warga Kelurahan Kebon Besar Kota Tangerang, Psikografi: Sebagai sarana untuk menyampaikan informasi, khususnya untuk warga Kelurahan Kebon Besar Kota Tangerang.

\section{Program Media}

Perancangan desain komunikasi visual sebagai media informasi pada Kelurahan Kebon Besar Kota Tangerang ini dilakukan menggunakan software Adobe Photoshop CS 6, dimana penggunaannya sangat cocok untuk membuat desain sebagai media informasi karena software yang digunakan cukup ringan, mudah digunakan dan salah satu software terbaik yang paling banyak digunakan untuk melakukan proses desain.

\section{Konsep Kreatif}

Konsep kreatif yang akan dituangkan ke dalam media-media penunjang informasi pada program sosialisasi yang dilakukan oleh Kelurahan Kebon Besar Kota Tangerang dengan menampilkan visual yang lebih mengarah kepada teknologi sesuai dengan perkembangan hidup yang lebih modern. Setiap desain disertai dengan Logo Kota Tangerang, gambar pendukung desain, serta terdapat teks yang menarik dan sudah disesuaikan penempatannya untuk menginformasikan isi dari setiap desain mengenai program sosialisasi yang akan berlangsung. Selain itu terdapat warna yang digunakan untuk mendukung desain yang dibuat agar terlihat menarik, serta menyesuaikan warna berdasarkan konsep desain kegiatan program sosialisasi yang akan dibuat agar desain lebih hidup dan memiliki daya tarik pada penyampaian informasinya.

\section{Strategi Kreatif}

Tampilan desain yang kreatif dengan kesan modern ditambah dengan unsur-unsur penting dalam mengkomunikasikan informasi seperti teks, gambar dan warna merupakan strategi kreatif yang ingin disampaikan. Dimana semua elemen-elemen yang ada saling terhubung dalam menciptakan sebuah desain yang menarik. Adapun teknik menciptakan ide dalam proses pembuatan desainnya, yaitu penyesuaian layout desain, pemilihan teks yang tepat, pemilihan warna yang sesuai, menentukan penempatan desain dan penyempurnaan tampilan desain.

\section{Strategi Visual}

Agar mendapat banyak perhatian dari masyarakat, informasi yang efektif dan menarik merupakan strategi yang harus disampaikan kepada masyarakat. Informasi dapat dilakukan dengan melalui berbagai media komunikasi visual, dengan mencantumkan identitas instansi, bahasa yang menarik, serta foto atau gambar-gambar animasi yang dapat menarik masyarakat. Penyajian visual ini dibentuk melalui software adobe photoshop CS 6 yang kemudian dilakukan untuk membuat tampilan desain yang menampilkan informasi pada media yang digunakan, yaitu media cetak. Strategi visual ini menggunakan pendekatan emosional, karena tampilan desain yang dipadukan dengan warna yang nyaman dilihat sehingga menciptakan rasa tenang dan gambar pendukung sesuai dengan desain yang dibuat sehingga menciptakan kesan ketertarikan dan memotivasi pada setiap tampilan visualnya. Adapun gaya penyajian grafis pada perancangan desain ini terkesan modern karena dibuat dengan desain yang sederhana, clean dan dengan perpaduan warna sebagai variasi untuk dapat menjadi daya tarik, serta memfokuskan penyajian informasi dengan gaya penyampaian yang lembut agar audience dapat memahami informasi yang terdapat pada desain.

\section{Pengertian Desain}

Desain adalah suatu cara untuk merancang sesuatu yang sebelumnya sudah direncanakan mengenai struktur dan bentuk yang akan dibuat. Setelah rancangannya telah diperoleh, maka langkah selanjutnya adalah melakukan implementasi. Dalam mengimplementasikan suatu desain untuk menghasilkan seperti yang telah direncanakan, membutuhkan tahapan-tahapan proses desain yang sebelumnya sudah ditentukan.

\section{Proses Desain}


Proses pembuatan desain sebagai media informasi pada Kelurahan Kebon Besar Kota Tangerang dilakukan secara bertahap sesuai dengan tahapan yang telah ditentukan untuk mendapatkan hasil rancangan yang menarik dan efektif. Dari proses desain ini terdapat desain yang dihasilkan, diantaranya ada desain poster peringatan hari sumpah pemuda, desain spanduk peringatan hari pahlawan, desain brosur festival kampung pemuda, desain poster imunisasi dan desain poster bantuan pangan non tunai (BPNT). Terdapat 3 (tiga) tahapan proses desain yaitu layout kasar, layout Komprehensif dan final artwork.

\section{Layout Kasar}

Layout kasar adalah gambaran yang memperlihatkan komposisi tata letak dari desain yang ingin dibuat menggunakan coretan atau seketsa hitam putih dengan pensil yang dibuat secara manual sebagai panduan pada saat proses desain menggunakan aplikasi komputer.

\section{Layout Kasar Poster Sumpah Pemuda}

Dalam hal ini penulis membuat seketsa yang menggambarkan layout kasar poster hari sumpah pemuda dengan memperhatikan unsur warna dan gambar yang sesuai dengan desain untuk selanjutnya akan dipasang di lingkungan Kelurahan Kebon Besar Kota Tangerang jika sudah memasuki tahap final artwork.

\section{Layout Kasar Spanduk Hari Pahlawan}

Dalam hal ini penulis membuat seketsa yang menggambarkan layout kasar spanduk hari pahlawan yang berisi ucapan selamat hari pahlawan yang akan dipasang di lingkungan Kelurahan Kebon Besar Kota Tangerang setelah memasuki tahap final artwork. Terdapat juga pemilihan gambar pendukung seperti gambar para pahlawan yang diikuti oleh ucapan selamat hari pahlawan dan kata-kata motivasi agar desain terlihat lebih hidup dan dapat mengobarkan semangat nasionalisme.

\section{Layout Kasar Brosur Festival Kampung Pemuda}

Dalam hal ini penulis membuat seketsa yang menggambarkan layout kasar brosur festival kampung pemuda dengan ide desain menambahkan gambar wali kota dan wakil walikota beserta logo kota Tangerang sebagai identitas dari desain dan acara yang akan berlangsung. Terdapat juga kata-kata ajakan untuk mengikuti event festival kampung pemuda dan tempat khusus pada desain untuk menampilkan perlombaan dan waktu dilaksanakannya festival kampung pemuda.

\section{Layout Kasar Poster Imunisasi}

Dalam hal ini penulis membuat seketsa yang menggambarkan layout kasar poster imunisasi yang berisi informasi mengenai ajakan untuk mencegah penyakit untuk si buah hati dengan melakukan imunisasi yang nantinya akan dipasang di lingkungan Kelurahan Kebon Besar Kota Tangerang. Adapun ide pada poster imunisasi ini bertujuan untuk membuat daya tarik dan menyadarkan diri dengan teks yang mengandung unsur ajakan untuk lebih menjaga kesehatan si buah hati dengan cara melakukan imunisasi. Penggambaran animasi anak kecil pada desain ini dirasa sangat cocok dan sesuai dengan tema desain poster imunisasi.

\section{Layout Kasar Brosur Bantuan Pangan Non-Tunai (BPNT)}

Dalam hal ini penulis membuat seketsa yang menggambarkan layout kasar brosur bantuan pangan non-tunai yang akan diletakan didepan kantor atau mading Kelurahan Kebon Besar Kota Tangerang, serta menyebarkannya ke masyarakat dengan bantuan organisasi karang taruna. Terdapat penempatan khusus pada informasi yang dianggap penting seperti waktu dilaksanakannya program bantuan pangan non tunai (BPNT).

\section{Layout Komprehensif}

Layout Kompherensif adalah suatu proses desain yang sudah memasuki tahap komputerisasi dan pewarnaan setelah mendapatkan gambaran melalui layout kasar. Pada tahap ini desain gambar sudah mendekati komposisi final, namun masih belum selesai seutuhnya, karena masih mengalami proses revisi. 


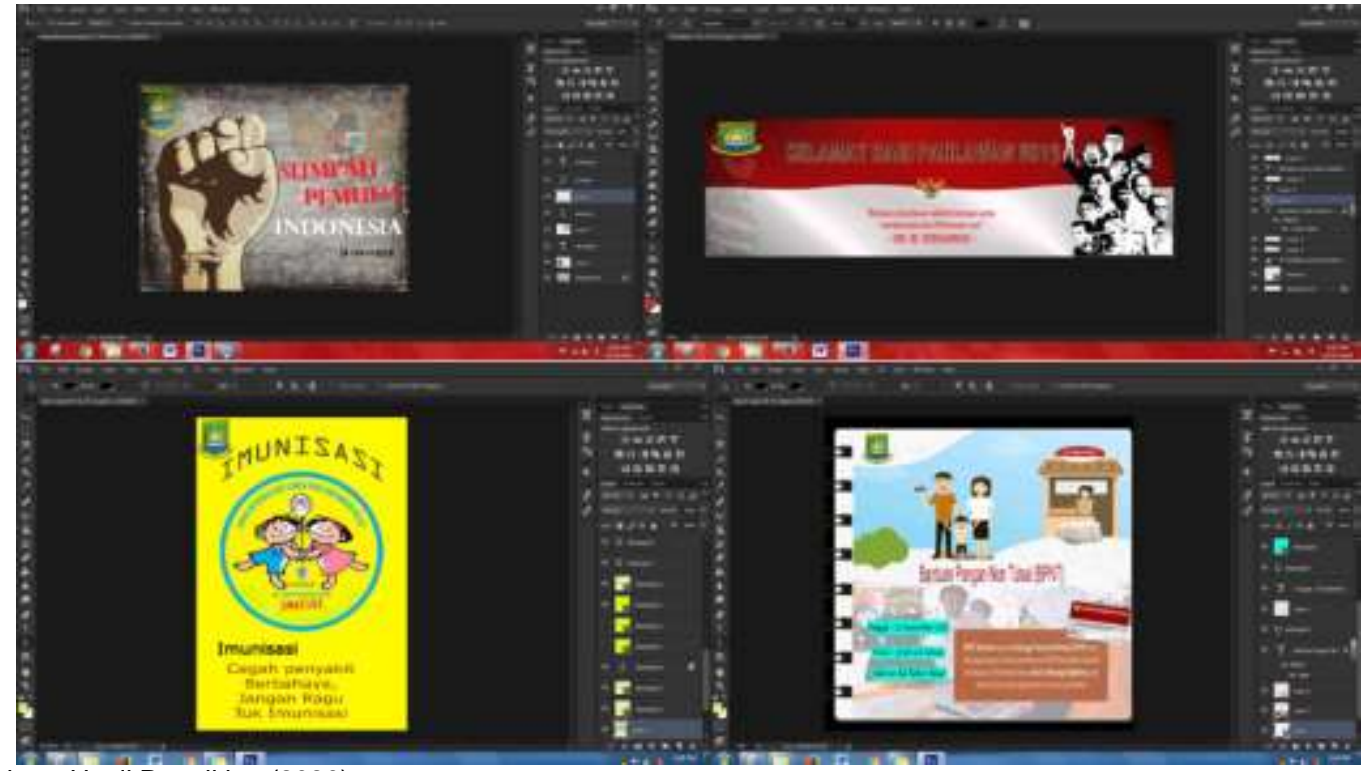

Sumber : Hasil Penelitian (2020)

\section{Final Artwork}

Gambar 2. Layout Kompherensif

Final Artwork adalah hasil akhir atau final desain dari Layout Kompherensif yang telah diperbaiki, dimana pada tahap ini desain sudah siap dicetak (dipublikasikan).

\section{Final Artwork Poster Peringatan Hari Sumpah Pemuda}

Poster ini dibuat untuk mengucapkan selamat hari sumpah pemuda ke-91 Tahun yang ada dilingkungan Kelurahan Kebon Besar Kota Tangerang. Susunan warna yang menggunakan perpaduan warna coklat, hitam agar terlihat tegas, dan menampilkan foto tangan yang tergenggam serta burung garuda pancasila yang telah di Transparency.

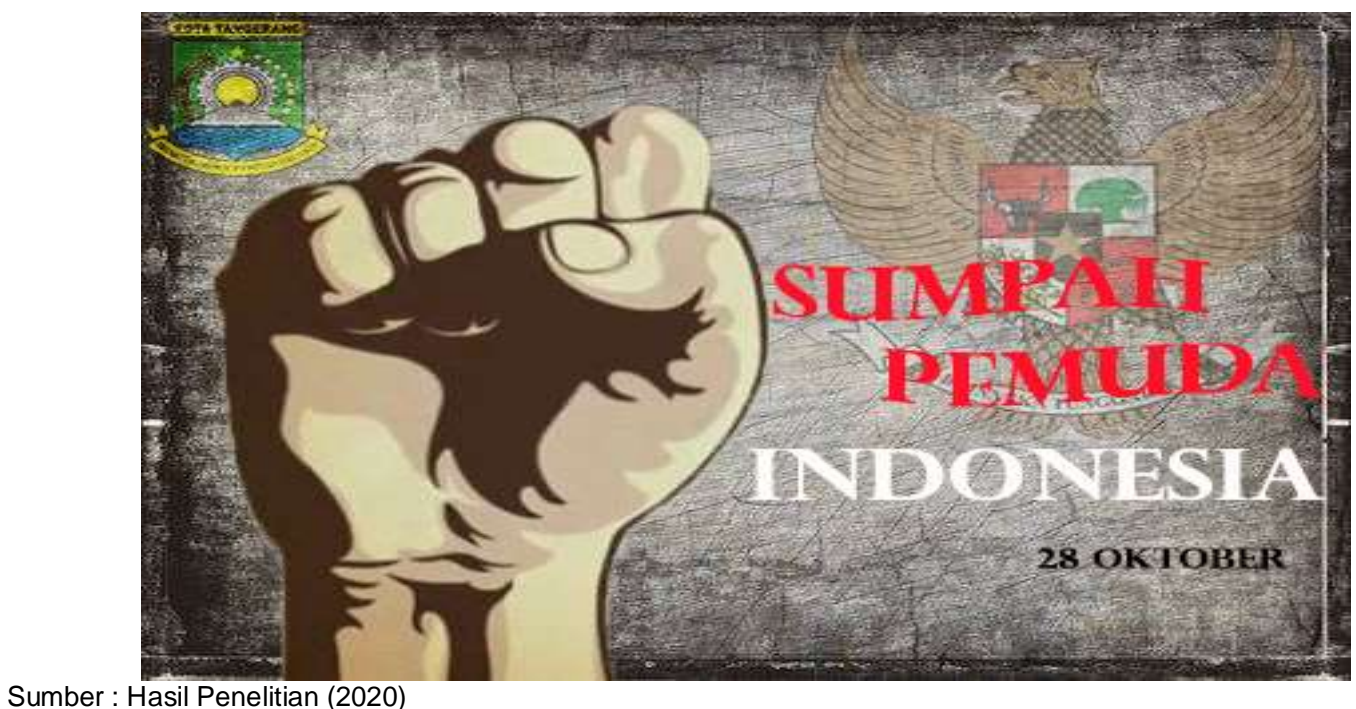

Sumber : Hasil Penelitian (2020)

Gambar 3. Final Artwork Poster Sumpah Pemuda

\section{Final Artwork Spanduk Peringatan Hari Pahlawan}

Desain spanduk ini dibuat untuk mengucapkan Selamat Mempringati Hari Pahlawan Tahun 2019 kepada seluruh masyarakat dan keluarga Kelurahan Kebon Besar Kota Tangerang. Dengan bertuliskan "SELAMAT HARI PAHLAWAN 2019 dan Bangsa Yang Besar Adalah Bangsa Yang Menghargai Jasa Pahlawannya". Desain spanduk ini menggunakan logo Kota Tangerang, burung garuda pancasila, dan gambar pahlawan nasional serta menggunakan warna merah dan putih untuk background spanduk. 


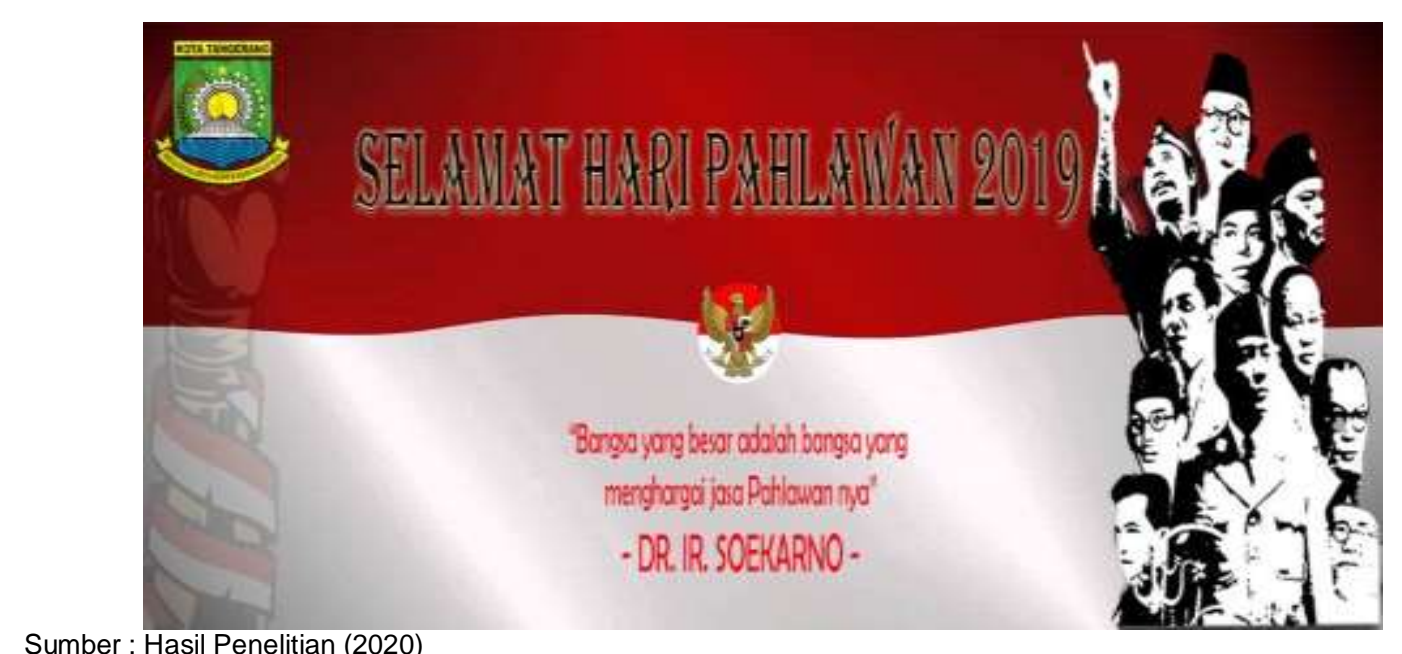

Sumber : Hasil Penelitian (2020)

Gambar 4. Final Artwork Spanduk Peringatan Hari Pahlawan

\section{Final Artwork Brosur Festival Kampung Pemuda}

Desain brosur festival kampung pemuda ini dibuat dengan menggunakan susunan warna biru agar terlihat manis dan mencantumkan macam-macam perlombaan Dan menampilkan beberapa foto yang disusun rapi agar terlihat elegan dengan memberikan kalimat pemberitahuan kepada Masyarakat Kebon Besar Kota Tangerang. Desain brosur ini akan menjadi media informasi yang akan diletakan dimading, pada event-event tertentu dan disebarluaskan kepada masyarakat kelurahan Kebon Besar Kota Tangerang melalui organisasi karang taruna.

Sumber : Hasil Penelitian (2020)

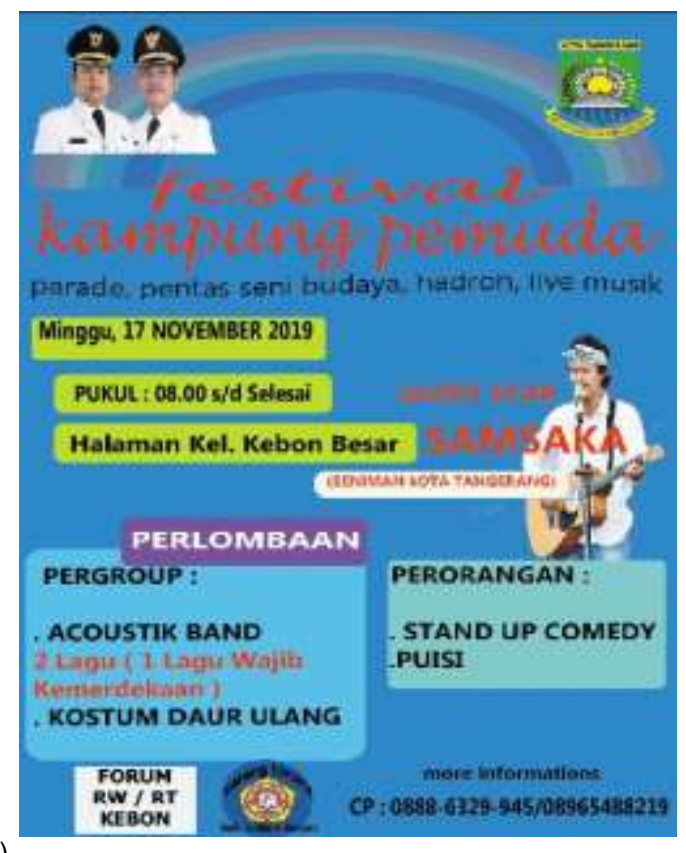

Gambar 5. Final Artwork Brosur Festival Kampung Pemuda

\section{Final Artwork Poster Imunisasi}

Pada desain poster imunisasi ini mencantumkan gambar kartun anak agar terlihat menarik dan logo Kota Tangerang yang bertuliskan "Cegah penyakit berbahaya, jangan ragu tuk imunisasi" bertujuan agar masyarakat bisa mencegah penyakit buah hatinya melalui program Imunisasi. Pada desain poster ini menggunakan background warna kuning agar terlihat cerah dan jelas. 
Sumber : Hasil Penelitian (2020)

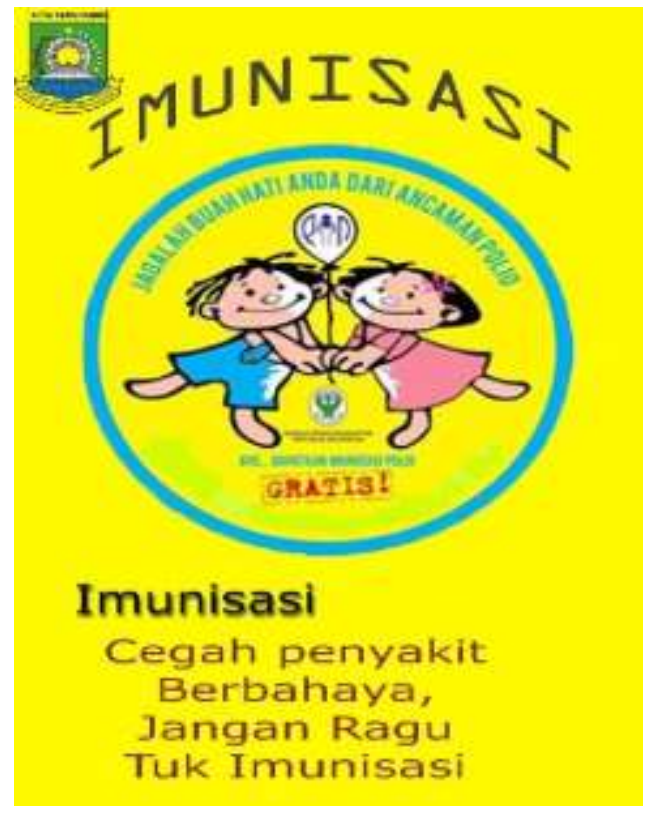

Gambar 6. Final Artwork Poster Imunisasi

\section{Final Artwork Brosur Program Sosialisasi BPNT}

Desain brosur ini menggunakan background dengan warna putih, menggunakan logo Kota Tangerang dan mencantumkan beberapa gambar pendukung agar terlihat menarik. Dengan memberikan kalimat pemberitahuan kepada Masyarakat Kelurahan Kebon Besar Kota Tangerang mengenai pengambilan Program BPNT (Bantuan Pangan Non-Tunai).

Sumber : Hasil Penelitian (2020)

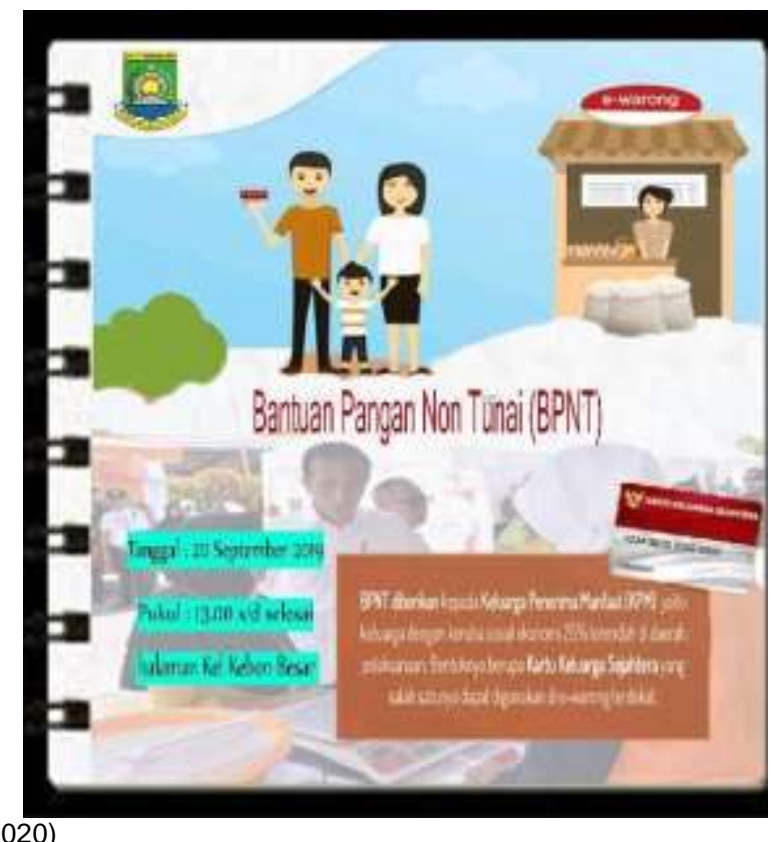

Gambar 7. Final Artwork Brosur Program Sosialisasi BPNT

\section{Kesimpulan}

Peran Desain Komunikasi Visual yang dibuat dengan semenarik mungkin dengan informasi yang jelas, dapat meminimalisir terjadinya kesalahan dalam menyampaikan informasi pada Kelurahan Kebon Besar Kota Tangerang mengenai kegiatan program sosialisasi yang masih menggunakan komunikasi lisan dari satu orang ke orang lainnya. Sehingga mencegah kemungkinan terjadinya kesalahan penyampaian maupun penerimaan informasi dari berbagai 
pihak. Dengan adanya media informasi yang tersentuh dengan teknologi, Kelurahan Kebon Besar Kota Tangerang dapat menciptakan suatu informasi yang unik serta menciptakan ketertarikan bagi masyarakat yang melihatnya.

\section{Ucapan Terima Kasih}

Terimakasih banyak kepada Kelurahan Kebon Besar Kota Tangerang yang telah memberikan izin kepada peneliti untuk melakukan penelitian.

\section{Referensi}

[1] P. Rustianingtyas, "Laporan Keuangan Sebagai Alat Komunikasi," Jurnal Paradigma Madani, vol. 2, no. 2, pp. 93-104, 2015.

[2] I. Permatasari, "Karakteristik Keterampilan Komunikasi Lisan Calon Guru Fisika Pada Mata Kuliah Fisika SMP," Jurnal Inovasi Pendidikan Fisika dan Integrasinya, vol. 01, no. 02, pp. 43-48, 2018.

[3] T. Dharmawan, "Musik Klasik dan Daya Ingat Jangka Pendek pada Remaja," Jurnal IImiah Psikologi Terapan., vol. 03, no. 02, pp. 370-382, 2015.

[4] T. S. Tambunan, Glosarium istilah pemerintahan. Jakarta: Praenadamedia Group, 2016.

[5] A. Supriyono, S. I. Idrus, I. C. Buana, I. N. Sihombing, and M. H. Noviar, Modul Presentasi dengan Infografis. Jakarta: Bidang Perencanaan Diklat DPR RI, 2019.

[6] Q. L. Qamardani and T. Wahaab, "PERANCANGAN BUKU KOMIK PENGENALAN PROFESI DESAINER GRAFIS," in e-Proceeding of Art \& Design, 2016, vol. 5, no. 3, pp. $1-7$.

[7] A. Wedianto, H. L. Sari, and Y. S. H, "Analisa Perbandingan Metode Filter Gaussian , Mean Dan Median Terhadap Reduksi Noise," Jurnal Media Infotama, vol. 12, no. 1, pp. 21-30, 2016.

[8] K. A. Surono, "Penanaman Karakter Dan Rasa Nasionalisme Pada Kegiatan Ektrakurikuler Pramuka Di Smp N 4 Singorojo Kabupaten Kendal," Indonesia Journal Conservation., vol. 6, no. 1, pp. 23-30 2018.

[9] F. R. S. Edi, Teori Wawancara Psikodignostik. Yogyakarta: LeutikaPrio, 2016.

[10] E. Ernawati, A. Johar, and S. Setiawan, "Implementasi Metode String Matching Untuk Pencarian Berita Utama Pada Portal Berita Berbasis Android (Studi Kasus: Harian Rakyat Bengkulu)," Pseudocode, vol. 6, no. 1, pp. 77-82, 2019.

[11] S. Palinggi and L. R. Allolinggi, "Analisa Deskriptif Industri Fintech di Indonesia: Regulasi dan Keamanan Jaringan dalam Perspektif Teknologi Digital," Jurnal Ekonomi dan Bisnis, vol. 6, no. 2, pp. 177-192, 2019. 